FEY, R.; MALAVASI, U. C.; MALAVASI, M. M. Silvopastoral system: a review regarding the family agriculture. Revista de Agricultura Neotropical, Cassilândia-MS, v. 2, n. 2, p. 26-41, abr/jun. 2015.

\title{
SILVOPASTORAL SYSTEM: A REVIEW REGARDING THE FAMILY AGRICULTURE
}

\section{RUBENS FEY ${ }^{1}$, UBIRAJARA CONTRO MALAVASI ${ }^{2}$, MARLENE DE MATOS MALAVASI ${ }^{2}$}

\footnotetext{
${ }^{1}$ Universidade Federal da Fronteira Sul (UFFS), Laranjeiras do Sul/PR, Brazil, rubens.fey@uffs.edu.br; ${ }^{2}$ Universidade Estadual do Oeste do Paraná (UNIOESTE), Centro de Ciências Agrárias, Marechal Cândido Rondon/PR, Brazil, biramalavasi@yahoo.com.br, biramalavasi@yahoo.com.br
}

\begin{abstract}
The Silvopastoral System (SPS) is understood as an interaction between trees, animals and pasture. The knowledge about the component action potentialities and limitations determines the system success or failure. The potentialities that can be highlighted are the heat reduction for animals and the improvement of the forage quality provided by the trees shadows. The reduction of pasture production at degraded systems is a limitation. The SPS is a sustainable option for family properties that produce meat and milk. The economical, social and cultural limitations are a problematic issue for the SPS adoption and it slows down the number of producers implementing it, specially the called family agriculture. The public policy deficiency to improve it, the lack of technical assistance preparation on the issue and the limited scientific knowledge about the system economical advantages are some of the difficulties to increase the SPS in Brazil.
\end{abstract}

KEYWORDS: Agroforestry systems, pasture, smallholder.

\section{SISTEMA SILVIPASTORIL: UMA REVISÃO COM APONTAMENTOS À AGRICULTURA FAMILIAR}

\begin{abstract}
RESUMO: O Sistema Silvipastoril (SSP) envolve a interação entre árvores, animais e pastagem. O conhecimento das potencialidades e limitações da ação de cada componente em relação aos demais componentes determina o sucesso ou fracasso na adoção do sistema. Como benefícios alcançados pode-se destacar a amenização do calor aos animais e a melhoria da qualidade da forragem proporcionada pela sombra das árvores. Já a redução na produção da pastagem em sistemas mal manejados destaca-se como limitação. O SSP é uma opção sustentável às propriedades familiares produtoras de carne e de leite. Porém, limitações de ordem econômica, social e cultural compõem uma barreira para a adoção do SSP por produtores principalmente por aqueles que fazem parte da denominada agricultura familiar (AF). A reduzida atuação de políticas públicas para incentivar esta área, a falta de preparo da assistência técnica no assunto, e o limitado conhecimento científico sobre o retorno econômico do sistema são alguns dos elementos que dificultam o crescimento do SSP em unidade da AF no Brasil.
\end{abstract}

PALAVRAS-CHAVE: Sistemas agroflorestais, pastagem, pequeno agricultor.

\section{INTRODUCTION}

Silvopastoral Systems (SPS) constitutes a variation of the agroforestry systems formed by associations between trees, animals and grass in one environment for one period 
(FRANKE; FURTADO, 2001). The main objective of the system is to support a better use of the natural resources (light, soil and water) in order to increase the productive diversity of the property (NEPOMUCENO; SILVA, 2009).

SPS was first implemented with the objective of reducing soil losses by erosion at pastures in New Zealand. Nevertheless, other benefits from that system make it a sustainable way to obtain social, economic and environmental development for rural populations (MOSQUERA-LOSADA et al., 2009).

Most of the researches of SPS are done in New Zealand, where the system is a part of the government program (BENAVIDES et al., 2009). In Brazil, several configurations of the system were studied with native and exotic species (PACIULLO et al., 2009; OLIVEIRA et al., 2009).

Difficulties to manage the system are common because of the interaction needed among forestry, agronomy, animal science and veterinary knowledge. The challenge is to figure out the best arrangement (tree, pasture and animal) and manage it according to the edaphoclimatic limitations and to be an economically/social/environmentally viable alternative to family agriculture.

\section{SPS Components}

One of the SPS sustainability requirements is concerned with the adequate choice of system species (ANDRADE et al., 2004).

\section{Tree component}

The tree component is what allows the SPS be called a forestry system. The SPS may be composed by native or exotic species and its choice depends on the strategy of the producer, who may explore fruits (ARAKAKI et al., 2009), wood (GYENGE et al., 2002), rubber (MAGALHÃES et al., 2001; PEREIRA, 2007), leaves or oil.

Andrade et al. (2002) and Oliveira et al. (2009) studied native plants from Amazonia and Acre, respectively, and confirmed that species such as "baginha" (Stryphnodendron guianense (Aubl.) Benth.), "faveira" (Schizolobium amazonicum), "bordão-de-velho" (Samanea tubulosa), and "jurema" (Chloroleucon mangense var. mathewsii) are suitable for SPS, although no commercial product is obtained from those trees.

The more commonly species used in Brazilian SPS are those with fast growth and commercial value. Eucalyptus species are the most used, mainly because of the quantity and the different uses of its wood, the fast growth and the genetic selection of some species intending to use as paper fabrication and cellulose (GOMIDE et al., 2005).

Tree density and practices (pruning and thinning) in this system must be evaluated regarding the microclimate formed by the trees. Souza et al. (2010) observed that using eucalyptus tier of 8,18 and 28 meters obtained reductions of $10.2 ; 12.5$ and $20.8 \%$ of the radiant thermal charge because reduction in leaves porosity exposed to sunlight. The decreased thermal charge results in thermal comfort for animals during the hottest periods of the day (LEME et al, 2005).

In regions with less daylight seasons, trees with deciduous characteristics present advantages over perennial ones in SPS. The loss of the leaves allows the light incidence and consequently the understory forage growth (BENAVIDES et al., 2009). Physic nut (Jatropha curcas L.) has that characteristic, but the studies related to its use in SPS are only starting (FEY et al., 2014). 
Therefore, in SPS it is important to focus on the system components (tree, pasture and animal) and not only on the tree component. This understanding is determinant for SPS success.

\section{Pasture component}

Besides the adequate choice of cultivated species, the pasturage must have the capacity to grow in different conditions of photosynthetically active photons flow density (PAPFD) (FELDHAKE; BELESKY, 2009).

PAPFD variation is a SPS characteristic and it is controlled by the crown density which is the main factor that limits forage growth of this system (DEVKOTA et al., 2009). Some forage species can morphologically adapt to the system reducing the leaves limbo thickness and increasing the chlorophyll density, in order to increase the efficiency of the light uptake (BELESKY, 2005; BENAVIDES et al., 2009).

Soares et al. (2009) evaluated the behavior of 11 summer perennial grass under several light regimes. These authors observed that dry matter production was negatively affected by shading, while the content of gross protein was higher of shaded parts in relation to full sun. Axonopus catharinensis was the most tolerant species to shading and Cynodon sp. hybrid Tifton-85 the least tolerant.

This is not only about choosing the more tolerant species to shading; the forage also needs to be productive, in order to attend animals' demands. Focusing on it and considering the work of Soares et al. (2009) previously quoted, Brachiaria brizantha cv. Marandu was considered the most appropriated species. Andrade et al. (2001) observed that shading was not the only factor that limits Tanzania grass growth in a SPS.

Nitrogen $(\mathrm{N})$ deficiency should be considered in $\mathrm{N}$ poor soils and the consort between forager and $\mathrm{N}$ fixers is desirable. In another study, Andrade et al. (2003) verified dry mass increased production of the pasture Panicum maximum cv. Mombaça consorted with the leguminous Stylosanthes guianensis cv. Mineirão in SPS with eucalyptus. Nevertheless, those authors observed that this leguminous is not sufficiently adapted to shading. The forage leguminous Arachis pintoi cv. Belmonte species presented higher tolerance among others in respect of the tolerance to artificial shading (ANDRADE et al., 2004).

\section{Animal component}

Ovine and bovine livestock on open range is among the most common form of food supply in tropical regions. Nevertheless, in those regions the hot seasons limit animal food ingestion at the hottest periods of the day resulting in thermal stress that also affects hormonal balance (infertility problems) reducing meat or milk production (RENSIS; SCARAMUZZI, 2003).

The benefits of SPS to animals were first reported by cattlemen. They observed that a herd took shelter at the available shade during the hottest hours of the day. The SPS may provide the necessary thermal comfort to animals to both ovine and bovine. In Rondônia State, the ovine livestock was optimized in SPS with rubber tree (MAGALHÃES et al., 2001).

The South and Southwest regions and the State of Mato Grosso do Sul in Brazil are important meat and milk producers based on the bovine herd. The SPS provided an important increment for producers' income, mainly because of its effects on soil, microenvironment, forage and animals. These effects resulted not only from the choice of the tree component, forage and animal species, but mainly from the variation of the appropriate management of SPS components (BENAVIDES et al., 2009). 


\section{SPS effects on Soil, Microenvironment, Pasture and Animal}

\section{Soil}

The physical, chemical and microbiological properties of soil under SPS are different when compared to areas that did not adopt that system (POLLOCK et al., 2009; POWER et al., 2003; REIS et al., 2010).

\section{Chemistry}

Soil $\mathrm{pH}$ depending on the tree species used may vary compared to pasturage in open fields (BENAVIDES et al., 2009). Chang et al. (2002) observed lower soil pH compared to the open field where Pinus radiata was used. Reis et al. (2010) reported that $\mathrm{pH}$ was higher in the $0-2 \mathrm{~cm}$ soil layer and lower in the $2-10 \mathrm{~cm}$ layer under a SPS in Lagoa Santa/MG. Those variations are related to the density and tree species used. It was observed that deciduous trees such as Populus varied according to the increase of soil $\mathrm{pH}$. Benavides et al. (2009) suggested the use of Populus as $\mathrm{pH}$ bioremediation for acid soils because of its ability to increase soil $\mathrm{pH}$.

The $\mathrm{pH}$ variation affects the nutrient availability (NOVAIS et al., 2007) and grasses have different capabilities to extract nutrients from the soil. Brachiaria brizantha $c v$. Marandu, previously considered adequate for being cultivated in SPS, presented optimum growth at pH 6.5 according to Souza Filho et al. (2000).

The spatial distribution of trees in pasture decreases the concentration of feces in specific sites, such as close to drinking spots. It occurs because of the increase in site availability allowing animal thermal comfort (FERREIRA et al., 2011). Those authors also observed that, despite the more homogeneous distribution of feces at the pasturage total area compared to the open field, $64 \%$ of the solid excrements were deposited in the crown projection, and the feces after mineralization provided nutrients for forage growth.

Litterfall resulting from leaves, flowers, fruits and tree branches (ARATO et al., 2003) are important source for nutrient cycling (DIAS-FILHO, 2006). Nutrient concentration from litterfall varies according to the tree species. Litterfall in SPS has a quickly mineralization because of the favorable conditions of the forest understory microclimate to microorganisms. Nevertheless, Reis et al. (2010) could not verify differences in the N, P, K and Ca contents in SPS soils after 26 years in Minas Gerais State compared to the adjacent pasturage with no trees, possibly because of the low allotment of animals and the high $\mathrm{C} / \mathrm{N}$ ratio.

\section{Physics}

Organic matter from animal feces deposited under tree crown projection and fallen leaves with nutrients availability after mineralization may increase soil stability (HUANG et al., 2005) allowing a reduction of soil loss by erosion independently of soil class.

Another effect of the organic matter addition is the reduction of its bulk density making soil more resistant to compaction (BRAIDA et al., 2006) an important property in areas with animal traffic (trampling).

Studies about the SPS effects on changes of soil physical properties and erosion control are still rare in the scientific community. Those studies need to be explored, as it has already been pointed out by Benavides et al. (2009).

Macro and microfauna 
Agroforestry systems differ in relation to their effects on the soil microbiological diversity. In Amazônia soils, Barros et al. (2003) observed greater microbiological diversity at SPS when compared to the agrosilvopastoral system.

In India, Tripathi et al. (2005) reported that soil biology in SPS was constituted by different orders of invertebrates, and that the size of each population varied according to the tree species and pasture. The reported variation, according to those authors, occurred because of the capacity of the system to provide nutrients (recycling and animals' feces) and because of the maintenance of adequate soil humidity and temperature for each species.

When SPS was constituted by Zizyphus nummularia tree species and Cenchrus ciliaris grass it favored the development of Acari, myriapods and other arthropods populations. Systems with Acacia senegal, Capparis Decidua and Acacia nilotica with the grass Digitaria marginatus, Elusine compressa and Cenchrus biflorus, respectively favored coleopteran, isopteran and collembolan populations.

Dias et al. (2007) worked with Brachiaria brizantha cv. Marandu in SPS and detected differences in the soil microfauna diversity, when tree species was a nitrogen fixer regarding the $\mathrm{C} / \mathrm{N}$ ratio of the vegetal material added to the soil. There are larger earthworm populations in grass located below tree crowns in comparison with the adjacent pasture (JARDEVESKI; SILVA, 2005). Earthworms improve the stability of soil aggregation (soil physical quality) according to Blanchart et al. (2004).

The increased biodiversity on macro and microfauna in SPS is significant (MACADAM et al., 2007), although data characterizing invertebrate population with tree arrangements and pasture in different regions of Brazil still needs to be detailed.

\section{Microenvironment}

Microenvironment is defined, in this work, as the atmosphere located below and between crowns of the tree component.

\section{Wind Control}

The spatial arrangement formed by the trees may modify wind intensity (windbreaker) over the pasture. If it is installed in line and perpendicularly to the predominant winds, it makes the air displacement over the pasture slower.

Strong winds may cause damage by abrasion on leaf surfaces, which may increase water losses by transpiration with a reduction of forage productivity. Other effect on plants submitted to strong winds is the reduction of photosynthesis, caused by the stomatal closure as part of the defense mechanisms to water loss by transpiration.

Slower wind at the higher soil layers (pasture) maintains water vapor more condensed in that region, decreasing the evaporation rate of the soil water (BRANDLE et al., 2004), therefore holding soil humidity for a longer period.

\section{PAPFD density}

Photosynthetically active photons flow density (PAPFD) measured at $\mu$ mol photons $\mathrm{m}^{-}$ ${ }^{2} \mathrm{~s}^{-1}$ varies along the day and according to the season and the local latitude. In SPS the sun radiation management may mean the success or failure of the system (FELDHAKE; BELESKY, 2009). The interception of sun radiation by the tree crowns limits grass development (BUERGLER et al., 2005) in the forest understory depending on tree height, tree vertical structure, number and distribution of branches, leaves density, area and angle, and the leaf reflectance. 
Operations such as thinning or pruning are resources to adjust PAPFD to the forage below the trees. However, tree density variation (ROZADOS-LORENZO et al., 2007) and the association with pasture tolerant to higher shading levels (SOARES et al., 2009) are the most used and the most studied techniques. Rozados-Lorenzo et al. (2007) obtained an inverse relation between leaf area index of the trees and pasture production below them in SPS. Soares et al (2009) found that forage production was negatively affected by shading, but forage crude protein increased with shading compared with open sky.

\section{Temperature}

The different configurations (species, densities and handling) of SPS may modify the air and soil temperature, in the microclimate below tree crowns.

Sousa et al. (2007) observed a reduction of $2-3{ }^{\circ} \mathrm{C}$ in the maximum air temperature obtained in the SPS understory compared to full sun. Tree density and height are variables that interfere the most with air and soil temperatures of a SPS (Souza et al., 2010).

Soil surface temperature is modified by tree shade. Using densities of 200 trees per hectare of 10 year-old Pinus radiata, soil temperature at $30 \mathrm{~cm}$ depth was $1{ }^{\circ} \mathrm{C}$ colder than with densities lower than 100 trees per hectare (BENAVIDES et al. 2009).

The shelter provided by trees decreases the losses caused by infrared radiation (BRANDLE et al., 2004), which can reduce the risk of frost in the cold weather (FIEDHAKE, 2002).

\section{Soil humidity}

Soils with low water availability may limit forage growth caused by stomatal closure, which is a defense mechanism to reduce water loss by transpiration (TAIZ; ZEIGER, 2004). The relation between the plant hydraulics regime and evapotranspiration is determinant for the water availability at the pasturage.

In regions or seasons with sparse rains, rain drops intercepted by tree crowns are evaporated resulting in significant water losses (GYENGE et al., 2002). The competitive effect among the plants may also be the reason why some authors found less water availability in SPS than in open field soil (GYENGE et al., 2002), in spite of different soil portions exploited (BENAVIDES et al., 2009).

However, the lower winds intensity resulting from the windbreaker effect, and the larger shading area that occurs over SPS pasturages reduces water loss by evaporation which justifies the higher humidity reported by some authors.

\section{Pasture}

Forage grasses tolerant to shading shows low $\mathrm{N}$ content, low digestion ability and high fibers content which limits the voluntary ingestion by the animals and, therefore, the meat or milk production (LIMA et al., 2001).

The genetic expression potential of the pasture in SPS is mainly limited by the restriction of the active photosynthetically light retained by the tree component (BUERGLER et al., 2005). The light passage control through tree crowns can be regulated by management practices such as pruning to adequate understory pasture production (GUEVARA-ESCOBAR et al., 2007).

Forage growth is not proportional to the rate of light availability due to tree crowns (MCELWEE; KNOWLES, 2000). Some grass species tolerate shading and, therefore, modifies morphology (BELESKY, 2005). 


\section{Production x Quality}

The reduction of forage dry matter production in SPS is described by several authors (ANDRADE et al., 2003; HUSSAIN et al., 2009; SOARES et al., 2009). The main issue is the light restriction which depends on the tree crown according to the description in PAPFD density section.

Benavides et al. (2009) listed studies reporting a negative relationship between the tree crown widths, shading and grass dry matter production. However, Brachiaria decumbens tolerated shading levels until 50\% without losses of dry matter production (PACIULLO et al., 2008). Paciullo et al. (2009) also could not find differences at the dry matter production of $B$. decumbens cultivated in monoculture or under moderate shading.

The mechanisms used by some species to stand shading levels (an increased growth rate of leaf, stem and chlorophyll content) may improve bromatological quality of some forages under full sunlight (ANDRADE et al., 2004; NEEL et al., 2008; PAUCIULLO et al., 2008). Castro et al. (2009) reported double of protein content in B. decumbens grass with $45 \%$ shading compared to full sunlight during the summer. The results were mainly attributed to the improved soil fertility provided by the tree component which fixed nitrogen.

Peri et al. (2007) established an increased percentage of gross protein in Dactylis glomerata from 18.6 to $22.5 \%$ and a decreased PAPFD. Lin et al. (2001), studying the morphologic changes and the variations at the bromatological composition of 30 foragers species with a SPS potential usage, found unaltered or a bigger fiber contents in neutral acid detergent with a higher percentage of shading over plants. The most common morphological alterations were the bigger space of the inner elements, the increasing leaf area and the reduction of the leaf specific weight. The above authors also observed unaltered protein contents in the leguminous forage leaves by shading treatments, different from the grass in which the protein contents was higher for the most studied species.

Data obtained by Paciullo et al. (2007) also indicated the potential use of Brachiaria decumbens in SPS. Those authors did not obtain decreased dry mass production by the forage until 35\% of shading. The lowest PAPFD also provided increased gross protein contents, reduced fiber contents in neutral detergent and increased digestibility in vitro of dry matter at the forest understory pasturage.

Besides shading tolerance, selection of forager species for a SPS must be based on the adaptability to the local edaphclimatic conditions and it must show dry mass production and nutritional levels adequate to animal component (ANDRADE et al., 2004). Brachiaria (marandu and massai), Arachis pintoi cv. Belmonte (leguminous), Axonopus catharinensis and Panicum maximum species were considered potentially able to use (ANDRADE et al., 2004; GOBBI et al., 2009; SOARES et al., 2009), while Tifton-68 was considered less tolerant to shading (CARVALHO et al. 2002).

Cynodon sp. hybrid Tifton-85 even though it presents higher protein content when shaded, it reduced its dry mass production from $24,014 \mathrm{~kg} \mathrm{ha}^{-1}$ in open field to under 10,000 $\mathrm{kg} \mathrm{ha}^{-1}$ in SPS by Pinus taeda in a 15 x 3 m planting spacing (SOARES et al., 2009).

\section{Animal}

Animal production results from an interaction of several processes such as genetics, quantity and quality of food and the water provided health, lactation phase and pregnancy in lactating females (ROCHE et al., 2009). 
The expression of those processes is related to optimum physical and physiological factors that determine animals' production, and their adaptability to the environment (LEME et al., 2005). Bovines are very sensitive to heat. In addition, animals are not capable to dissipate enough heat to maintain homoeothermic (thermal stress), which is determinant for the reduction of milk or meat production (RENSIS; SCARAMUZZI, 2003).

The micro-environment temperature reduction provided by tree shading of SPS may reduce thermal stress of animals, mainly at the hottest hours of the hottest summer days. In Dutch cows, the milk production is already damaged when the animals are submitted to temperatures different from the thermoneutrality (BARBOSA et al., 2004; PORCIONATO et al., 2009) which peaks at $26^{\circ} \mathrm{C}$.

Shading provided by the SPS tree component is the main factor that develops animals' welfare under pasturage (LEME et al., 2005). Its effects are deleterious when the temperatures at full sunlight may exceed $26^{\circ} \mathrm{C}$. Under those conditions, cattle increases heat transference for body surface, increases skin temperature in order to increase heat loss by convection and radiation, increases transpiration rate in order to lose heat by sweating, increases respiratory volume in order to increase the evaporative heat loss by transpiration and culminates with the reduction of production.

The lowest fertility rate of animals may also be a consequence of thermal stress (RENSIS; SCARAMUZZI, 2003). Garcia-Ispierto et al. (2007) observed a decrease of 33\% on the conception rate in cows submitted to temperatures higher than $30{ }^{\circ} \mathrm{C}$. Hormonal alterations are caused by heat stress and may cause reproductive problems such as delayed puberty, irregular estrous cycle, ovarian cists, low ovulation rate, anestrous and embryonic mortality due to the compromising of oocyte competence and inhibition of embryonic development (GUZELOGLU et al., 2001).

Tree shade not only reduces heat but also provides better forage quality resulting from the higher concentration of soil nutrients already described above.

\section{The context of Family Agriculture (FA) in Brazil}

Family Agriculture (FA) in Brazil is an operational concept from the State to delimitate a target public for its policies (SCHNEIDER, 2003) which involves the categories previously known as small holder, small proprietary, peasant, subsistence agriculturist, low income agriculturist, participants of agrarian reform programs and small farmers (NEVES, 2007). This concept of family agriculture is based on the triad family-production-work and is understood as a unity of agricultural production where property and work are closely linked to the family.

FA is characterized as a rural enterprise of land with less than 50 hectares where at least $80 \%$ of the income and work force are obtained in the property and in the family according to the Brazilian federal law n. 11,326 of June $24^{\text {th }}, 2006$.

The need of FA protection by the government policies was mainly originated because of the sector vulnerability to the Green Revolution consequences (GOLLIN et al., 2005) implemented during the 50s, founded on the large scale production with high technology, showing as a result an excellent productivity (CAVALLI, 2001). The Green Revolution (GR) initiated a technological process of workers reduction needed in the field, substituted by machines and equipment's. GR happened mainly for the products grouped as commodities (soybean, maize, wheat). The productive facilities increased the product offer, reducing the profitability and generating the need of a large scale production to reach a minimal income for the family income reducing the profitability by product unity. 
During the 40 years from the beginning of the GR movement previously characterized, some attitudes had been taken to the imposed system which included the transference of a part or the entire work force to the cities - rural exodus - or an alternative productive model for the commodities, under the market rules, which allowed more profitability by produced unit.

The lack of adequate technical orientation supporting landowners lead many to move from rural to urban settlements, especially in the late 80 s and early $90 \mathrm{~s}$ in Brazil. That movement generated urban social problems, but this discussion and details are not the objective of this text.

Only in the 1990s, government and non-government programs were intensified helping small agriculturists to protect themselves from the scale economy and to promote better management options. The production of bioenergy, meat, milk, fruits and vegetables and the vertically production at agroindustry are part of the alternatives. The major government program that supports that process is PRONAF ("Programa Nacional de Apoio à Agricultura Familiar") [National Support Program to the Family Agriculture] initiated in 1995.

\section{SPS as an income alternative for FA}

The FAs are also an important instrument to generate profits for the family property (COSTA et al., 2002; SANTOS; PAIVA, 2001). SPS is an alternative for sustainability of family agriculture. SPS is characterized by its components (tree, pasture and animal) and by its variable properties related to the chosen species and the different management options, according to previous sections of this review.

The tree component furnishes a new commercial product to landowner, important to compose productive diversity in FA (FLEIG et al., 1993). It can be wood, oil, resin, leaf, bark, rubber or nuts, as a function of the species. The species choice depends, among other factors, on the local commercial demand or on the logistic to attend markets located away from the production area.

Wood used in the property as firewood or building structures constitutes a benefit from the tree component in addition to meat or milk in SPS. The income reduction occurred in the last decades promoted degradation of FA wellbeing may be partly recovered with the use of wood from SPS.

Some government programs encourage the plantation of specific species at FA (PENSAF, 2006) such as the physic nut (Jatropha curcas L.). Besides the benefits to the animals by the reduction of thermal stress and the improvement of the forage quality (according to the described above), the addition of tree species of commercial interest is one of the challenges for researchers.

At small properties, the strategy to increase the products quantity in order to increase the income is important, but reducing the losses, mainly soil, is even more important, the benefits offered by the SPS to reduce the losses by soil erosion are significant.

Besides the advantages previously described, there is the possibility of using the resources more efficiently (fixed capital and work force) at the small property. In addition, the introduction of the wood component in the property allows the farmer to distribute part of the profits in a long term diluting risks and transforming part of his SPS from financial deficit (ZARNOTT et al., 2009).

The plantation configuration of the tree component in SPS generally in line and equally spaced, with the forage area organized by animal size and number allows optimization of agricultural production. This perception, and the SPS economic benefits already described 
in this review, enables to improve life quality of families who live in small land units in Brazil.

\section{SPS limitations in FA}

Despite the existence of several studies showing SPS advantages, implementation of the system still sporadic and discussion of reasons of such must be better understood (DAGANG; NAIR, 2003). Family units of the agricultural production and diversified activities are part of the sustainability strategy. However, competitiveness demands efficiency on each process.

Low education level of family farmers makes use of SPS difficult. In the state of Rio Grande do Sul family farmers attended by PRONAF, research indicated that income has a high correlation with farmers education level, considering that the participants studying average was 5.9 years (ANJOS et al., 2004). It may be even lower in the North and Northwest regions of Brazil. Such fact makes management of new activities even more difficult.

There is no adequate technical assistance network available to family farmers that want to implement SPS (BALBINO et al., 2011), which demands several management decisions in order to integrate trees, animals and pasture in the same area and time frame.

The introduction of the tree component, which production details are not well established compared to the traditional products (commodities), makes it even harder for the FA to invest in SPS (POLZL et al., 2003).

Part of this undefined situation happens because of the confusing understanding of the Brazilian forest legislation (SPAROVEK et al., 2012). The issue involves the forest code as well as discussions and variations around it by different regulation of each Brazilian state. The decision to plant trees in property, which results are expected at medium and long term, turns out to be even more difficult since the law project $n$. 1876/99 proposed alterations at the Brazilian forest code.

Another issue that reduces SPS use by FA in Brazil is the insufficient quantity of demonstrative units that show results about the system at different Brazilian regions. The Paraná state, through the URT ("Unidade de Referência Tecnológica") [Technological Reference Unit] headed by Embrapa Florestas [Embrapa Forests] is the first state to rely on a program to fulfill the demand in a systematic way, but it still has no long term data about the SPS advantages and it does not have URT in every Parana region.

Knowledge of SPS generated by the scientific community is relatively vast, but it discusses basically technical aspects. Publications dealing with the economic aspects of SPS are still very limited (LEE, 2005). Information associated to the need of initial cost and long term return was pointed out as a restrictive issue for SPS adoption by the FA at MedicilândiaPA.

Ways to reduce limitations of SPS use include: credit offered by PRONAF to dilute the initial implantation costs; scientific results showing economic advantages by SPS for different Brazilian regions; rural extension practices in SPS; increase of demonstrative SPS units for the FA.

\section{REFERENCES}

ANDRADE, C.M.S.; GARCIA, R.; COUTO, L.; PEREIRA, G.O. Fatores limitantes ao crescimento do capim-tanzânia em um sistema agrossilvipastoril com eucalipto, na região dos cerrados de Minas Gerais. Revista Brasileira de Zootecnia, Viçosa-MG, v.30, n.4, p.1178- 
$1185,2001$.

ANDRADE, C.M.S.; GARCIA, R.; COUTO, L.; PEREIRA, G.O.; SOUZA, A.L. Desempenho de seis gramíneas solteiras ou consorciadas com Stylosanthes guianensis cv. Mineirão e Eucalipto em sistema silvipastoril. Revista Brasileira de Zootecnia, Viçosa-MG, v.32, n.6, p.1845-1850, 2003.

ANDRADE, C.M.S.; VALENTIM, J.F.; CARNEIRO, J.C. Árvores de baginha (Stryphnodendron guianense (Aubl.) Benth.) em ecossistemas de pastagens cultivadas na Amazônia Ocidental. Revista Brasileira de Zootecnia, Viçosa-MG, v.31, n.2, p.574-582, 2002.

ANDRADE, C.M.S.; VALENTIM, J.F.; CARNEIRO, J.C.; VAZ, F.A. Crescimento de gramíneas e leguminosas forrageiras tropicais sob sombreamento. Pesquisa Agropecuária Brasileira, Brasília-DF, v.39, n.3, p.263-270, 2004.

ANJOS, F.S.; GODOY, W.I.; CALDAS, N.V.; GOMES, M. C. Agricultura familiar e políticas públicas: o impacto do Pronaf no Rio Grande do Sul. Revista de Economia e Sociologia Rural, Rio de Janeiro-RJ, v.42, n.4, p.529-548, 2004.

ARAKAKI, A.H.; SCHEIDT, G.N.; PORTELLA, A.C.; ARRUDA, E.J. COSTA, R.B. O baru (Dipteryx alata Vog.) como alternativa de sustentabilidade em área de fragmento florestal do Cerrado, no Mato Grosso do Sul. Interações, Campo Grande-MS, v.10, n.1, p.31-39, 2009.

ARATO, H.D.; MARTINS, S.V.; FERRARI, S.H.S. Produção e decomposição de serapilheira em um sistema agroflorestal implantado para recuperação de área degradada em viçosa-MG. Revista Árvore, Viçosa-MG, v.27, n.5, p.715-721, 2003.

CASTRO, C. R. T. D., GARCIA, R., CARVAlHO, M. M.; FREITAS, V. D. P. Efeitos do sombreamento na composição mineral de gramíneas forrageiras tropicais. Revista Brasileira de Zootecnia, Viçosa-MG, v. 30, p. 1959 - 1968, 2001. (Suplemento 6)

BALBINO L.C.; CORDEIRO, L.A.M.; PORFÍRIO-DA-SILVA, V.; MORAES, A.; MARTÍNEZ, G.B.; ALVARENGA, R.C.; KICHEL, A.N.; FONTANELI, R.S.; SANTOS, H.P.; FRANCHINI, J.C.; GALERANI, P.R. Evolução tecnológica e arranjos produtivos de sistemas de integração lavoura-pecuária-floresta no Brasil. Pesquisa Agropecuária Brasileira, Brasília-DF, v.46, n.10, p.i-xii, 2011.

BARBOSA, O.R.; BOZA, P.R.; SANTOS, G.T.; SAKAGUSHI, E.S.; RIBAS, N.P. Efeitos da sombra e da asperão de água na produção de leite de vacas da raça holandesa durante o verão. Acta Scientiarum Animal Sciences, Maringá-PR, v.26, n.1, p.115-122, 2004.

BARROS, E.; NEVE, A.; BLANCHART, E.; FERNENDES, E.C.M.; WANDELLI, E.; LAVELLE, P. Development of the soil macrofauna community under silvopastoral and agrosilvicultural systems in Amazonia. Pedobiologia, Elsevier, v.47, n.3, p.273-280, 2003.

BELESKY, D. P. Growth of Dactylis glomerata along a light gradient in the central Appalachian region of the eastern USA: II. Mechanisms of leaf dry matter production. Agroforestry Systems, Springer, v. 65, p. 91-98, 2005.

BENAVIDES, R.; DOUGLAS, G.B.; OSORO, K. Silvipastoralism in New Zealand: review of effects or ebvergreen and deciduous trees on pasture dynamics. Agroforest Systems, Springer, v.76, n.2, p.327-350, 2009.

BLANCHART, E.; ALBRECHT, A.; CHEVALLIER, T.; HARTMANN, C. The respective reles of roots and earthworms in restoring physical properties of Vertisol under a Digitaria decumbens pasture (Martinique, WI). Agriculture, Ecosystems and Environment, Elsevier, 
v.103, n.2, p.343-355, 2004.

BRAIDA, J.A.; REICHERT, J.M.; VEIGA, M.; REINERT, D.J. Resíduos vegetais na superfície e carbono orgânico do solo e suas relações com a densidade máxima obtida no ensaio proctor. Revista Brasileira de Ciência do Solo, Viçosa-MG, v.30, n.3, p.605-614, 2006.

BRANDLE, J.R.; HODGES, L.; ZHOU, X.H. Windbreaks in North American agricultural systems. Agroforestry Systems, Springer, v. 61-62, n.1-3, p.65-78, 2004.

BUERGLER, A.L.; FIKE, J.H.; BURGER, J.A.; FELDHAKE, C.R.; MCKENNA, J.A.; TEUTSCH, C.D. Botanical composition and forage production in an Emulated Silvopasture. Agronomy Journal, v. 97, n.4, p.1141-1147, 2005.

CARVALHO, M.M.; FREITAS, V.P.; XAVIER, D.F. Início de florescimento, produção e valor nutritivo de gramíneas forrageiras tropicais sob condição de sombreamento natural. Pesquisa Agropecuária Brasileira, Brasília-DF, v.37, n.5, p.717-722, 2002.

CASTRO, C.R.T.; PACIULlO, D.S.C.; GOMIDE, C.A.M.; MULLER, M.D.; NASCIMENTO JUNIOR, E.R. Características agronômicas, massa de forragem e valor nutritivo de Brachiaria decumbens em sistema silvipastoril. Pesquisa Florestal Brasileira, Colombo-PR, n.60, p.19-25 (edição especial), 2009.

CAVALLI, S.B. Segurança alimentar: a abordagem dos alimentos transgênicos. Revista de Nutrição, Campinas-SP, v.14, n.2, p.41-46, 2001.

CHANG, S.X.; AMATYA, G.; BEARE, M.H.; MEAD, D.J. Soil properties under Pinus radiate - ryegrass silvopastoral system in New Zealand. Part I. Soil N and moisture availability, soil C, and tre growth. Agroforestry Systems, Springer, v. 54, n.2, p.137-147, 2002.

COSTA, R.B.; ARRUDA, E.J.; OLIVEIRA, L.C.S. Sistemas agrossilvipastoris como alternativa sustentável para a agricultura familiar. Revista Internacional de Desenvolvimento Local, Campo Grande-MS, v.3, n.5, p.25-32, 2002.

DAGANG, A.B.K.; NAIR, P.K.R. Silvopastoral research and adoption in Central América: recent findings and recommendations for future directions. Agroforestry Systems, Springer, v.59, n.2, p.149-155, 2003.

DEVKOTA, N.R.; KEMP, D.P.; HODGSON, J.; VALENTINE, I.; JAYA, K.I. Relationship between tree canopy height and the production of pasture species in a silvopastoral system based on alder trees. Agroforest Systems, Springer, v.76, n.2, p.363-374, 2009.

DIAS, P.F.; SOUTO, S.M.; CORREIA, M.E.F.; RODRIGUES, K.M.; FRANCO, A.A. Efeito de leguminosas arbóreas sobre a macrofauna do solo em pastagem de Brachiaria brizanta cv. Marandu. Pesquisa Agropecuária Tropical, Goiânia-GO, v.37, n.1, p.38-44, 2007.

DIAS-FILHO M.B. Sistemas silvipastoris na recuperação de pastagens tropicais degradadas. Revista Brasileira de Zootecnia, Viçosa-MG, v.35, n.1, p.535-553, 2006.

FELDHAKE, C.M.; BELESKY, D.P. Photosynthetically active radiation use efficiency of Dactylis glomerata and Schedonorus phoenix along a hardwood tree-induced light gradient. Agroforestry Systems, Springer, v.75, n.2, p.189-196, 2009.

FELDHAKE, C.M. Forage frost protection potential of conifer silvopasture. Agricultural and Forest Meteorology, Elsevier, v.112, n.1, p.123-130, 2002.

FERREIRA, L.C.B.; MACHADO FILHO, L.C.P.; HOETZEL, M.J.; LABARRÈRE, J.G. O efeito de diferentes disponibilidades de sombreamento na dispersão das fezes dos bovinos nas 
pastagens. Revista Brasileira de Agroecologia, Cruz Alta-RS, v.6, n.1, p.137-146, 2011.

FEY, R.; MALAVASI, U.C.; MALAVASI, M.M.; SCHULZ, D.G.; DRANSKI, J.A.L. Relações interdimensionais e produtividade de pinhão-manso (Jatropha curcas L.) em sistema silvipastoril. Semina: Ciências Agrárias, Londrina-PR, v. 35, n. 2, p. 613-624, 2014.

FLEIG, F. D.; SCHNEIDER, P.R.; BRUM, E.T. Análise econômica dos sistemas de produção com acácia-negra (Acacia mearnisii de Wild.) no Rio Grande do Sul. Ciência Florestal, Santa Maria - RS, v. 3, p.203-240, 1993

FRANKE, I.L.; FURTADO, S.C. Sistemas Silvipastoris, fundamentos e aplicabilidade. Rio Branco: Acre 51p. (documento 74), 2001.

GARCIA-ISPIERTO, I.; LOPEZ-GATIUS， F; BECH-SABAT，G.; SANTOLARIA， P.; YANIZ, J.L.; NOGAREDA, C.; RENSIS, F.; LOPEZ-BEJAR, M. Climate factors affecting conception rate of high producing dairy cows in northeastern Spain. Theriogenology, Elsevier, v. 67, n. 8, p. 1379-1385, 2007.

GOBBI, K. F.; GARCIA, R.; GARCEZ NETO, A. F.; PEREIRA, O. G.; VENTRELLA, M. C.; ROCHA, G. C. Características morfológicas, estruturais e produtividade do capimbraquiária e do amendoim forrageiro submetidos ao sombreamento. Revista Brasileira de Zootecnia, Viçosa-MG, v.38, n.9, p.1645-1654, 2009.

GOLLIN, D.; MORRIS, M.; BYERLEE, D. Technology adoption in intensive Post-Green revolution systems. American Journal Agricultural Economics, Oxford Journals, v.87, n.5, p.1310-1316, 2005.

GOMIDE, J.L.; COLODETTE, J.L.; OLIVEIRA, R.C.; SILVA, C.M. Caracterização tecnológica, para produção de celulose, da nova geração de clones de Eucalyptus do Brasil. Revista Árvore, Viçosa-MG, v.29, n.1, p.129-137, 2005.

GUEVARA-ESCOBAR, A.; KEMP, P.D.; MACKAY, A.D.; HODGSON, J. Pasture production and composition under poplar in a Hill environment in New Zealand. Agroforestry Systems, Springer, v.69, n.2, p.199-213, 2007.

GUZELOGLU, A.; AMBROSE, J.D.; KASSA, T.; DIAZ, T.; THATCHER, M.J.; THATCHER, W.W. Long- term follicular dynamics and biochermical characteristics of dominant follicles in dairy cows subjected to acute heat stress. Animal Reproduction Science, Elsevier, v.66, n.1, p.15-34, 2001.

GYENGE, J.E.; FERNÁNDEZ, M.E.; SALDA, G.D.; SCHLICHTER, T.M. Silvopastoral systems in Northwertern Patagonia II: water balance and water potencial in a stand of Pinus ponderosa and native grassland. Agroforestry Systems, Springer, v.55, n.1, p.47-55, 2002.

HUANG, P.M.; WANG, M.K.; CHIU, C.Y. Soil mineral-organic matter-microbe interactions: Impacts on biogeochemical processes and biodiversity in soils. Pedobiologia, Elsevier, v.49, n.6, p. 609-635, 2005.

HUSSAIN, Z.; KEMP, P.D.; HORNE, D.J.; JAYA, I.K.D. Pasture production under densely planted young willow and poplar in a silvopastoral system. Agroforestry Systems, Springer, v.76, n.2, p.351-362, 2009.

JARDEVESKI, R.; SILVA, V.P. Minhocas em uma pastagem arborizada na região noroeste do estado do Paraná, Brasil. Boletim Pesquisa Florestal, Colombo-PR, v. 25, n.51, p.17-31, 2005.

LEE, D.R. Agricultural sustainability and technology adoption: Issues and policies for developing countries. American Journal Agricultural Economics, Oxford Journals, v.87, 
n.5, p.1325-1334, 2005.

LEME, T.M.S.P; PIRES, M.F.A; VERNEQUE, R.S.; ALVIM, M.J.; AROEIRA, L.J.M. Comportamento de vacas mestiças holandês x zebu, em pastagem de Brachiaria decumbens em sistema silvipastoril. Ciência e Agrotecnologia, Lavras-MG, v.29, n.3, p.668-675, 2005.

LIMA, M.L.P.; BERCHIELLI, T.T.; NOGUEIRA, J.R.; RUGGIERI, A.C.; AROEIRA, L.J. M.; SALMAN, A.K.D.; SOARES, J.P.G. Estimativa de consumo voluntário do capimtanzânia (Panicum maximum, Jcq. Cv. Tanzânia) por vacas em lactação sob pastejo rotacionado. Revista Brasileira de Zootecnia, Viçosa-MG, v.30, n.2, p.1919-1924, 2001.

LIN, C.H.; MCGRAW, R.L.; GEORGE, M.F.; GARRETT, H.E. Nutritive quality and morphological development under partial shade of some forage species with agroforestry potencial. Agroforestry Systems, Springer, v.53, n.3, p.269-281, 2001.

MAGALHÃES, J.A.; COSTA, N.L.; PEREIRA, R.G.A.; TOWNSEND, C.R. Desempenho produtivo e reações fisiológicas de ovinos deslanados mantido sob seringal (Hevea brasiliensis). Revista Cientifica de Produção Animal, Areia-PB, v.3, n.1, p.77-82, 2001.

MACADAM, J.H.; SIBBALD, A.R.; TEKLEHAIMANOT, A.; EASON, W.R. Developing silvopastoral systems and their effects on diversity of fauna. Agroforestry Systems, Springer v.70, n.1, p.81-89, 2007.

MCELWEE, F.F.; KNOWLES, R.L. Estimating canopy closure and understory pasture production in New Zealand-grown poplar plantations. New Zealand Journal or Forestry Science, v.30, n.3, p.422-435, 2000.

MOSQUERA-LOSADA， M.R.; RODRIGUEZ-BARREIRA， S.; LÓPEZ-DÍAZ， M.L.; NÚNEZ-FERNÁNDEZ, E.; RIGUEIRO-RODÍGUEZ, A. Biodiverity and silvipastoral system use change in very acid soil. Agriculture, Ecosystems and Environment, Elsevier, v.131, n.3, p.315-324, 2009.

NEEL, J.P.S.; FELDHAKE, C.M.; BELESKY, D.P. Influence of solar radiation on the productivity and nutritive value of herbage of cool-season species of an understory swart in a mature conifer woodland. Grass and Forage Science, Wiley Online Library v.63, n.1, p.3847, 2008.

NEPOMUCENO, N.A.; SILVA, I.C. Caracterização de sistemas silvipastoris da região noroeste do estado do Paraná. Floresta, Curitiba-PR, v.39, n.2, p.279-287, 2009.

NEVES, D.P. Agricultura familiar: quantos ancoradouros! In: FERNANDES, B.M.; MARQUES, M.I.M.; SUZUKI, J.C. Geografia Agrária: teoria e poder. São Paulo-SP: Expressão Popular, p. 211-270, 2007.

NOVAIS, R.F.; ALVAREZ, V.V.; BARROS, N. F.; FONTES, R.L.F.; CANTARUTTI, R.B.; NEVES, J.C.L. Fertilidade do solo. Viçosa-MG: SBCS, 2007. 1017 p.

OLIVEIRA, T.K.; LUZ, A.S.; SANTOS, F.C.B.; LESSA, L.S. Crescimento de espécies arbóreas nativas em sistema silvipastoril no Acre. Amazônia: Ciência e Desenvolvimento, Belém-PA, v.4, n.8, p.121-126, 2009.

PACIULLO, D.S.C.; CARVALHO, C.A.B.; AROEIRA, L.J.M.; MORENZ, M.J.F.; LOPES, F. C.F.; ROSSIELLO, R.O.P. Morfofisiologia e valor nutritivo do capim-braquiária sob sombreamento natural e a sol pleno. Pesquisa Agropecuária Brasileira, Brasília-DF, v.42, n.4, p. 573-579, 2007.

PACIULLO, D.S.C.; CAMPOS, N.R.; GOMIDE, C.A.M.; CASTRO, C.R.T.; TAVELA, R.C.; ROSSIELLO, R.O.P. Crescimento de capim-braquiária influenciado pelo grau de 
sombreamento e pela estação do ano. Pesquisa Agropecuária Brasileira, Brasília-DF, v.43, n.7, p.917-923, 2008.

PACIULLO, D.S.C.; LOPES, F.C.F.; MALAQUIAS JUNIOR, J.D.; VIANA FILHO, A.; RODRIGUEZ, M.N.; MORENZ, M.J.F.; AROEIRA, L.J.M. Características do pasto e desempenho de novilhas em sistema silvipastoril e pastagem de braquiária em monocultivo. Pesquisa Agropecuária Brasileira, Brasília-DF, v.44, n.4, p.1528-1535, 2009.

PENSAF. PLANO NACIONAL DE SILVICULTURA COM ESPÉCIES NATIVAS E SISTEMAS AGROFLORESTAIS. Brasília-DF, 2006. 38p.

PEREIRA, J.P. Sistemas agroflorestais com a seringueira. Informe Agropecuário, Belo Horizonte-MG, v.28, n.237, p.32-38, 2007.

PERI, P.L.; LUCAS, R.J.; MOOT, D.J. Dry matter production, morphology and nutritive value of Dactylis glomerata growing under different light regimes. Agroforestry Systems, Springer, v.70, n.2, p.63-79, 2007.

POLLOCK, K.M.; MEAD, D.J.; MCKENZIE, B.A. Soil moisture and water use by pastures and silvopastures in a sub-humid temperate climate in New Zealand. Agroforestry Systems, Springer, v.75, n.3, p.223-238, 2009.

POLZL, W.B.; SANTOS, A.J.; TIMOFEICZYK JUNIOR, R.; POLZL, P. K. Cadeia produtiva do processamento mecânico da madeira- segmento da madeira serrada no estado do Paraná. Revista Floresta, Curitiba-PR, v.33, n.2, p.127-134, 2003.

PORCIONATO, M.A.F.; FERNANDES, A.M.; SARAN NETTO, A.; SANTOS, M.V. Influência do estresse calórico na produção e qualidade do leite. Revista Acadêmica de Ciências Agrárias Ambientais, Curitiba-PR, v.7, n.4, p.483-490, 2009.

POWER, I.L.; THORROLD, B.S.; BALKS, M.R. Soil properties and nitrogen availability in silvopastoral plantings of Acacia melanoxylon in North Island, New Zealand. Agroforestry Systems, Springer, v.57, n.3, p.225-237, 2003.

REIS, G.L.; LANA, A.M.Q.; MAURÍCIO, R.M.M.; LANA, R.M.Q.; MACHADO, M.R.; BORGER, I.; QUINZEIRO NETO, T. Influence of trees on soil nutrient pools in a silvopastoral system in the Brazilian Savannah. Plant Soil, Springer, v.329, n.1-2, p.185-193, 2010.

RENSIS, F.; SCARAMUZZI, R.J. Heat stress and seasonal effects on reproduction in the dairy cow - a review. Theriogenology, Elsevier, v.60, n.6, p.1139-1151, 2003.

ROCHE, F.R.; TURNER, L.R.; LEE, J.M.; EDMEADES, D.C.; DONAGHY, D.J.; MACDONALD, K.A.; PENNO, J.W.; BERRY, D.P. Weather, herbage quality and milk production in pastoral systems. 4. Effects on dairy cattle production. Animal Production Science, Csiro, v.49, n.3, p.222-232, 2009.

ROZADOS-LORENZO, M.J.; GONZÁLEZ-HERNÁNDEZ, M.P.; SILVA-PANDO, F.J. Pasture production under different tree species and densities in an Atlantic silvopastoral system. Agroforestry Systems, Springer, v.70, n.1, p.53-62, 2007.

SANTOS, M.J.C.; PAIVA, S.N. Os sistemas agroflorestais como alternativa economia em pequenas propriedades rural: estudo de caso. Ciência Florestal, Santa Maria-RS, v.12, n.1, p.135-141, 2002.

SCHNEIDER, S. Teoria social, agricultura familiar e plurariatividade. Revista Brasileira de Ciências Sociais, São Paulo-SP, v.18, n.51, p.99-121, 2003.

SOARES, A.B.; SARTOR, L.R.; ADAMI, P.F.; VARELLA, A.C.; FONSECA, L.; 
MEZZALIRA, R. Influência da luminosidade no comportamento de onze espécies forrageiras perenes de verão. Revista Brasileira de Zootecnia, Viçosa-MG, v.38, n.3, p.443-451. 2009.

SOUSA, L.F; MAURÍCIO, R.M.; GONÇALVES, L.C.; SALIBA, E.O.S.; MOREIRA, G.R. Produtividade e valor nutritivo da Brachiaria brizantha cv. Marandu em um sistema silvipastoril. Arquivo Brasileiro de Medicina Veterinária e Zootecnia, Belo Horizonte-MG, v.59, n.4, p.1029-1037, 2007.

SOUZA FILHO, A.P.S.; VELOSO, C.A. C.; GAMA, J.R.N. Capacidade de absorção de nutrientes do Capim-Marandu (Brachiaria brizantha) e da planta daninha malva (Urena lobata) em função do pH. Planta daninha, Viçosa-MG, v.18, n.4, p.443-450, 2000.

SOUZA, W. D., BARBOSA, O. R., MARQUES, J. D. A., COSTA, M. A. T., GASPARINO, E.; LIMBERGER, E. Microclimate in silvipastoral systems with eucalyptus in rank with different heights. Revista Brasileira de Zootecnia, Viçosa-MG, v. 39, n. 3, p. 685-694, 2010.

SPAROVEK, G.; BERNDES, G.; BARRETTO, A.G.O.P.; KLUG, I.L.F. The revision of the Brazilian Forest Act: increased deforestation or a historic step towards balancing agricultural development and nature conservation? Environmental Science \& Policy, Elsevier, v.16, p.65 $-72,2012$.

TAIZ, L.; ZEIGER, E. Fisiologia Vegetal. 3ed Porto Alegre: Artmed, 2004. 559p.

TRIPATHI, G.; RAM, S.; SHARMA, B.M.; SINGH, G. Soil faunal biodivertity and nutrient status in silvopastoral systems of Indian desert. Environmental Conservation, Cambridge Journals Online, v.32, n.2, p.178-188, 2005.

ZARNOTT, A.F.; PINHEIRO, S.L.G.; STROPASOLAS, V.L. Participação dos agricultores familiares de Canguçu no programa poupança florestal da Votarantin Celulose e Papel. Redes, Santa Cruz do Sul-RS, v.14, n.3. p.29-52, 2009. 